\title{
EFEKTIVITAS MEDIA KOMPUTERISASI DAN PERSEPSI SISWA DALAM MENINGKATKAN PRESTASI BELAJAR AKUNTANSI (SURVEI PADA SMK SWASTA DI JAKARTA PUSAT)
}

\author{
Anita Ria $^{1(*)}$, Didi Zainuddin ${ }^{2}$ \\ Universitas Indraprasta PGRI, Indonesia \\ anitarianita@gmail.com ${ }^{1}$, didiza.gadept@gmail.com²
}

Received: 27 Maret 2020

Revised: 28 Maret 2020

Accepted: 28 Maret 2020

\begin{abstract}
Penelitian ini bertujuan untuk mengetahui efektivitas penggunaan media komputerisasi dan persepsi siswa pada pelajaran akuntansi dalam meningkatkan prestasi belajar pelajaran akuntansi di SMK Swasta yang ada di Jakarta Pusat. Metode dalam penelitian ini adalah kuantitatif survey dengan teknik korelasional. Dari penelitian yang dilakukan diperoleh hasil bahwa koefisien korelasi ganda pengaruh variabel X1 dan X2 secara bersama-sama terhadap variabel $Y$ adalah sebesar 0,680. Maka berdasarkan nilai $r$ hitung korelasi tersebut memiliki hubungan keberpengaruhan dalam kategori Kuat. Sedangkan koefisien determinasinya sebesar 46,20\% dengan Persamaan regresi $\mathrm{Y}^{\wedge}=33,149+$ $0,143 \mathrm{X} 1+0,248 \mathrm{X} 2$. Sedangkan nilai koefisien regresi sebesar 0,248 dan 0,143 menunjukkan bahwa terdapat pengaruh positif variabel bebas X1 (Penggunaan Media Komputerisasi) dan X2 (Persepsi Siswa) secara bersama-sama terhadap variabel terikat Y (Prestasi Belajar mata pelajaran Akuntansi).
\end{abstract}

Keywords: Penggunaan Media Komputerisasi, Persepsi Siswa, Prestasi Belajar

(*) Corresponding Author: $\quad$ Anita Ria, anitarianita@gmail.com, 085695225639

How to Cite: Ria, Anita \& Zainuddin, Didi. (2020). Efektivitas Media Komputerisasi Dan Persepsi Siswa Dalam Meningkatkan Prestasi Belajar Akuntansi (Survei Pada Smk Swasta Di Jakarta Pusat). Research and Development Journal of Education, 6(2), 74-82.

\section{INTRODUCTION}

Pendidikan merupakan kebutuhan bagi setiap bangsa yang sedang membangun seperti halnya Indonesia. Dengan pendidikan diharapkan tercipta manusia Indonesia yang Kreatif dan kuat dalam menghadapi berbagai permasalahan sosial dan individu. Manusia yang kreatif dan kuat disebutkan dalam Undang-Undang Republik Indonesia Nomor 20 Tahun 2003 tentang Sistem Pendidikan Nasional, yaitu "manusia yang beriman dan bertakwa kepada Tuhan Yang Maha Esa, berakhlak mulia, sehat, berilmu, cakap, kreatif, mandiri, dan menjadi warganegara yang demokratis dan bertanggung jawab".

Proses pengembangan kemampuan dan pembentukan siswa menjadi manusia yang kreatif dan kuat memerlukan proses belajar. Definisi belajar yaitu suatu aktivitas atau proses untuk memperoleh pengetahuan, meningkatkan keterampilan, memperbaiki perilaku, sikap dan menguatkan kepribadian. Salah satu cara untuk mengukur hasil belajar adalah melalui prestasi belajar peserta didik. Prestasi belajar peserta didik adalah hasil penilaian dari kegiatan belajar yang telah dilakukan dan bentuk perumusan akhir yang diajarkan guru untuk melihat kemampuan siswa yang dinyatakan dalam bentuk simbol, angka, huruf maupun kalimat yang mencerminkan hasil yang sudah dicapai.

Efektivitas penggunaan media komputerisasi pada pelajaran akuntansi yang digunakan oleh sekolah dan juga persepsi siswa yang tepat dapat mempunyai pengaruh 
terhadap hasil belajar siswa. Media komputerisasi pada pelajaran akuntansi yang digunakan oleh sekolah akan mempengaruhi proses pembelajaran yang tepat atau tidaknya. Sedangkan persepsi belajar akan mempengaruhi karakter siswa dalam belajar diantaranya adalah pemahaman penerimaan pembelajaran, keaktifan siswa masuk sekolah, keaktifan siswa di dalam kelas, keaktifan siswa dalam mengikuti pelajaran dengan jadwal telah yang ditentukan, ketertiban dan kerapihan siswa dalam membuat catatan pelajaran serta kesediaan siswa waktu yang kosong di sekolah. Indikator persepsi tersebut akan mempengaruhi hasil belajar siswa.

Metode pembelajaran dan media pembelajaran yang dipakai oleh guru juga akan mempengaruhi nilai hasil belajar yang dicapai oleh siswa. Secara garis besar faktor yang mempengaruhi hasil belajar siswa Sekolah Menegah Kejuruan dibedakan menjadi dua yaitu faktor internal dan faktor eksternal. Slameto berpendapat (2010: 54), terdapat dua faktor yang mempengaruhi belajar yaitu faktor internal dan faktor eksternal. Faktor internal yaitu fisik/ jasmani, kematangan diri, kelelahan, psikologi berupa bakat, minat, kecerdasan, motivasi dan kemampuan kognitif maupun prestasi. Faktor eksternal yaitu lingkungan alam, lingkungan keluarga (cara mendidik, hubungan antar anggota keluarga, kondisi rumah, keadaan ekonomi keluarga, perhatian orang tua, latar belakang kebudayaan), lingkungan belajar (metode mengajar, media pembelajaran, kurikulum, relasi guru dengan siswa, relasi siswa dengan siswa, disiplin sekolah, waktu sekolah, standar pelajaran di atas ukuran, metode belajar, tugas rumah), dan lingkungan masyarakat (kegiatan siswa dalam masyarakat, teman bergaul, bentuk kehidupan masyarakat).

Di dalam pengelolaan pengajaran, penggunaan media komputerisasi akuntansi sebagai sarana media pembelajaran merupakan suatu masalah penting. Tanpa adanya kesadaran akan keharusan melaksanakan aturan yang sudah ditentukan sebelumnya pengajaran tidak mungkin mencapai target yang maksimal. Siswa yang memiliki persepsi yang baik pada suatu mata pelajaran akan dapat belajar dengan baik dan teratur sehingga akan menghasilkan hasil belajar yang baik. Guru juga merupakan faktor penting dalam pendidikan atau proses belajar mengajar. Menurut Nasution (1982): disebutkan guru dalam mengkomunikasikan pengetahuan pada peserta didiknya harusnya memiliki pengetahuan yang luas tentang bahan yang diajarkannya. Guru berperan sebagai penggerak, contoh dan tokoh identifikasi. Dengan demikian seorang guru seharusnya dapat memilih media pembelajaran yang dapat mendukung peran guru yang telah disebutkan. Penggunaan komputer sebagai media yang mereka gunakan akan juga berpengaruh pada siswa, karena seorang guru merupakan contoh dan tokoh identifikasi yang akan ditiru siswa. Jadi bagaimana penguasaan, ketertarikan dan pemahaman siswa tergantung pada bagaimana seorang guru menyampaikan pelajaran tersebut dengan semangat ataupun dengan lesu dan tanpa gairah. Secara kenyataannya pandangan guru terhadap siswa yang malas akan menghasilkan siswa yang malas juga. Bagaimanakah seorang guru akan membentuk siswa berprestasi jika guru itu sendiri memandang sebelah mata terhadap mata pelajaran yang dia ajarkan.

Pada dasarnya manusia adalah makhluk sosial yang sekaligus makhluk individu. Dimana terdapat perbedaan antara individu yang satu dengan yang lainnya, sehingga setiap informasi yang ada akan memiliki makna yang tidak sama oleh orang yang berbeda. Adanya perbedaan ini merupakan suatu alasan seseorang menyenangi suatu obyek, sedangkan orang lain belum tentu senang bahkan membenci obyek tersebut.

Hal ini sangat tergantung bagaimana individu menanggapi obyek tersebut dengan persepsinya. Suherman $(2005: 23)$ mengutip pendapat uttin dan Solso, mengemukakan, bahwa "persepsi merupakan tahap awal dari serangkaian pembuatan informasi". Persepsi adalah suatu proses penggunaan pengetahuan atau memperoleh dan penginterpretasikan stimulus (rangsangan) yang diterima oleh alat indera manusia (Sugono, $2008: 259$ ). 
Persepsi dapat diartikan sebagai suatu tanggapan langsung seseorang melalui proses yang sifatnya kompleks dalam menerima dan menginterpretasikan lingkungannya, sehingga dapat menyadari dan mengerti tentang objek tersebut dengan alat-alat inderanya. Adapun Menurut (Jalaluddin Rakhmat, 2011 : 50), persepsi merupakan pengalaman tentang objek, peristiwa, atau ikatan yang diperoleh dengan menyimpulkan informasi dan menafsirkan pesan. Dan Menurut (Irwanto, 1994 : 71) persepsi merupakan proses diterimanya rangsangan obyek kualitas, hubungan antara gejala maupun peristiwa sampai rangsangan itu disadari dan dimengerti, karena persepsi bukan sekedar penginderaan, maka bisa juga dinyatakan persepsi sebagai "the interpretation of experience"(penafsiran pengalaman).

Media pembelajaran yaitu alat bantu proses belajar mengajar. Segala sesuatu yang dapat dipergunakan untuk mengasah pikiran, perasaan, perhatian dan kemampuan atau keterampilan belajar sehingga dapat mendorong terjadinya proses belajar. Belajar merupakan proses aktif dan konstruktif melalui suatu pengalaman dalam memperoleh sesuatu atau informasi. Dan media pembelajaran berperan sebagai sumber yang dapat menambah pengetahuan bagi siswa. Artinya dengan media, peserta didik yang memperoleh pesan dan informasi bisa memunculkan pengetahuan baru bagi siswa. Dalam batas tertentu, media dapat menggantikan fungsi guru sebagai sumber informasi/pengetahuan bagi peserta didik secara sementara karena media pembelajaran sebagai sumber belajar merupakan suatu komponen system pembelajaran yang meliputi pesan, orang, bahan, alat, teknik, dan lingkungan, yang mempengaruhi hasil belajar peserta didik. (Mudhoffir,dalam Munadi, 2008). Adapun menurut (Trianto 2012 : 234) bahwa media pembelajaran merupakan eksistensi manusia yang memungkinkan mempengaruhi manusia tanpa ada kontak langsung dengannya.

\section{METHODS}

Metode yang digunakan dalam penelitian ini adalah kuantitatif survey dengan teknik korelasional. Variabel penelitian ini terdiri dari variabel terikat, yaitu Prestasi Belajar mata pelajaran Akuntansi (Y) dan dua variabel bebas, Penggunaan Media Komputerisasi $\left(\mathrm{X}_{1}\right)$, Persepsi siswa $\left(\mathrm{X}_{2}\right)$. Kuesioner penggunaan media aplikasi akuntansi ini disusun masing-masing dalam 40 butir pertanyaan yang selanjutnya diuji validitas butir dan reliabilitas instrument sehingga layak digunakan sebagai intrumen penelitian.

Tabel 1.

Indikator Penelitian

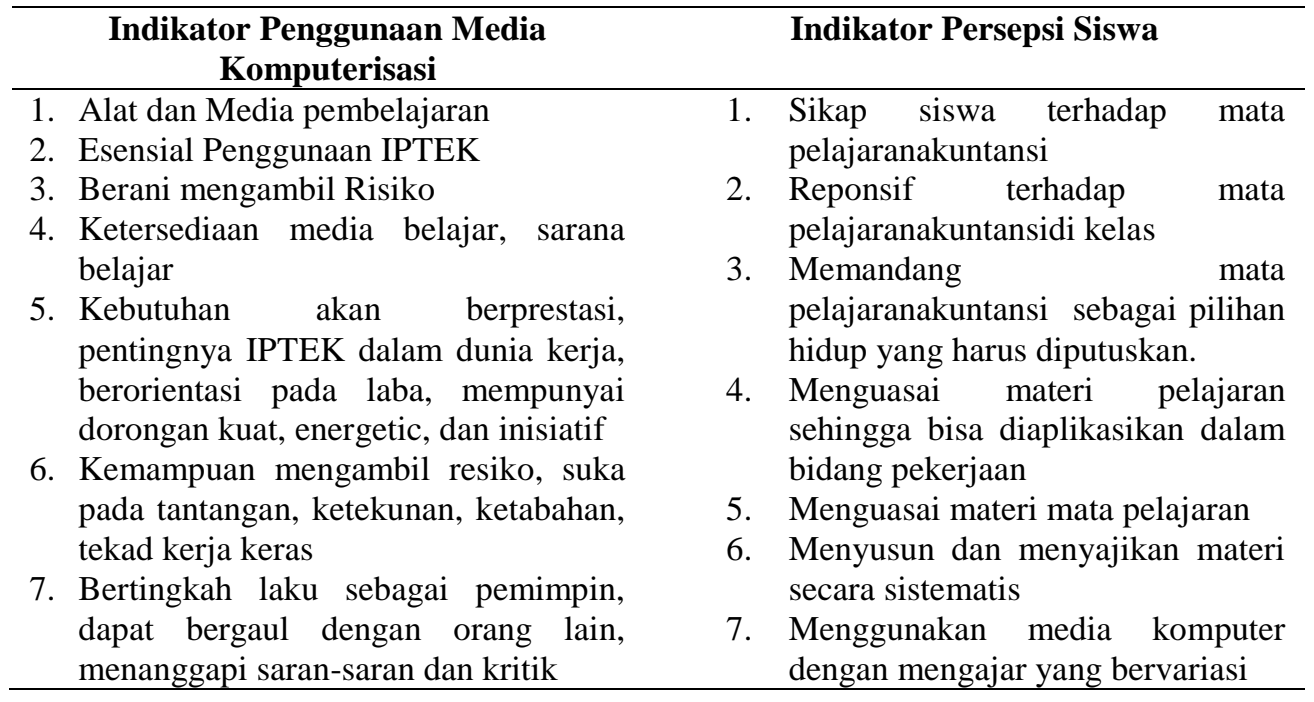




\begin{tabular}{llll}
\hline $\begin{array}{l}\text { 8. Inovatif dan kreatif, fleksibel, } \\
\text { mengetahui banyak hal }\end{array}$ & 8. & $\begin{array}{l}\text { Ketepatan dalam memilih metode } \\
\text { mengajar. }\end{array}$ \\
9. Pandangan jauh ke depan. & 9. $\begin{array}{l}\text { Mampu berkomunikasi dengan } \\
\text { orang lain. }\end{array}$ \\
\hline Sumber: Penulis 2020 & &
\end{tabular}

\section{RESULTS \& DISCUSSION}

\section{Pengujian Persyaratan Analisis}

Pengujian persyaratan analisis data yang dilakukan dalam penelitian ini adalah pengujian normalitas, homogenitas, dan linieritas garis regresi partial antara variabel bebas dan variabel terikat.

\section{Pengujian Normalitas Data}

Tabel 2.

Rekapitulasi Hasil Pengujian Normalitas

\begin{tabular}{llrr}
\hline & & $\begin{array}{c}\text { Unstandardized } \\
\text { Residual }\end{array}$ & $\begin{array}{c}\text { Standardized } \\
\text { Residual }\end{array}$ \\
\hline $\mathrm{N}$ & Mean & 60 & 60 \\
Normal Parameters ${ }^{\mathrm{a}, \mathrm{b}}$ & Std. Deviation & 5.29943298 & .98290472 \\
& Absolute & .110 & .110 \\
Most Extreme Differences & Positive & .110 & .110 \\
& Negative & -.081 & -.081 \\
Kolmogorov-Smirnov Z & & .851 & .851 \\
Asymp. Sig. (2-tailed) & & .464 & .464 \\
\hline Sumber : Penulis 2020 & & &
\end{tabular}

Pada tabel di atas terlihat bahwa nilai pada kolom Sig $=0,464>0,05$ pada metode Kolmogorov-Smirnov, sehingga $\mathrm{H}_{0}$ diterima, dengan kata lain bahwa data dari semua sampel pada penelitian ini berdistribusi normal. Untuk memperkuat hasil pengujian tersebut maka ditampilkan Histogram Normalitas Galat Baku, Grafik Normal P-P Plot Galat Baku, dan Grafik Normal Q-Q Plot untuk setiap sampel.

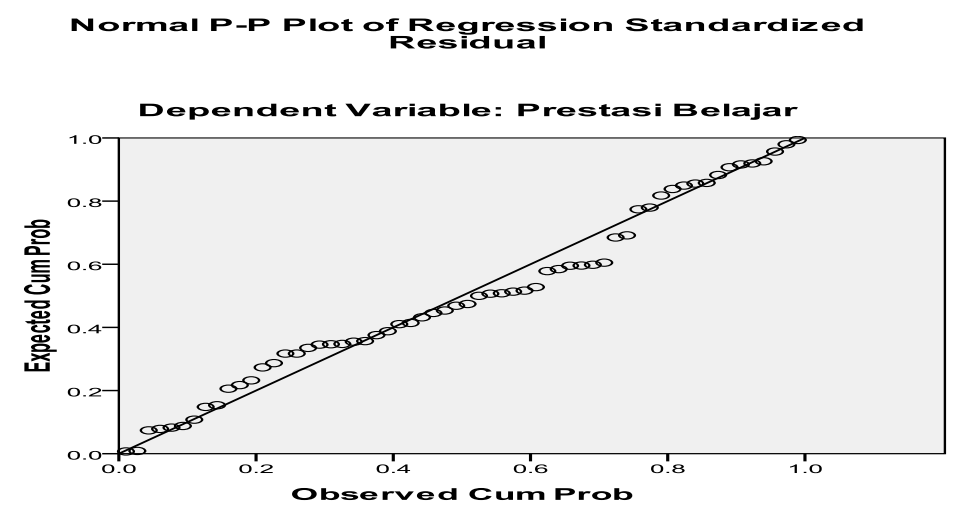

Gambar 1.

Scatter Plot Diagram Pencar 


\section{Pengujian Homogenitas}

Tabel 3.

Rekapitulasi Hasil Pengujian Homogenitas

\begin{tabular}{ccccc}
\hline & Levene Statistic & df1 & df2 & Sig. \\
\hline Penggunaan_Media_Komputerisasi & 2.421 & 19 & 32 & .093 \\
Persepsi_Siswa & 3.026 & 19 & 32 & .063 \\
\hline Sumber : Penulis 2020 & & & &
\end{tabular}

Pada tabel di atas terlihat bahwa nilai pada kolom Sig untuk semua sampel lebih besar dari 0,05, sehingga $\mathrm{H}_{0}$ diterima, dengan kata lain bahwa sampel-sampel tersebut berasal dari populasi yang homogen.

\section{Pengujian Linieritas garis Regresi}

Tabel 4.

Linieritas Garis Regresi Hubungan Antara Variabel $\mathrm{X}_{1}$ dengan Variabel Y

\begin{tabular}{|c|c|c|c|c|c|c|c|}
\hline & & & $\begin{array}{l}\text { Sum of } \\
\text { Squares }\end{array}$ & df & $\begin{array}{l}\text { Mean } \\
\text { Square }\end{array}$ & $\mathbf{F}$ & Sig. \\
\hline \multirow{6}{*}{$\begin{array}{l}\text { Prestasi_Belajar_Akunta } \\
\text { nsi* } \\
\text { Penggunaan_Media_Ko } \\
\text { mputerisasi }\end{array}$} & \multirow{4}{*}{$\begin{array}{l}\text { Between } \\
\text { Groups }\end{array}$} & (Combined) & 3843.367 & 30 & 128.112 & 3.317 & .001 \\
\hline & & Linearity & & & & & \\
\hline & & & 2237.306 & 1 & 2237.30 & 57.93 & .000 \\
\hline & & $\begin{array}{l}\text { Deviation } \\
\text { from Linearity }\end{array}$ & 1606.060 & 29 & 55.381 & 1.434 & .169 \\
\hline & \multicolumn{2}{|c|}{ Within Groups } & 1120.033 & 29 & 38.622 & & \\
\hline & \multicolumn{2}{|l|}{ Total } & 4963.400 & 59 & & & \\
\hline
\end{tabular}

Sumber : Penulis 2020

Pada tabel di atas terlihat bahwa nilai pada kolom Sig baris Linierity untuk semua sampel kurang dari 0,05, sehingga $\mathrm{H}_{0}$ diterima, dengan kata lain bahwa garis regresi hubungan antara varibel $\mathrm{X}_{1}$ dan variabel $\mathrm{Y}$ linier.

Tabel 5.

Linieritas Garis Regresi Hubungan Antara Variabel $\mathrm{X}_{2}$ dengan Variabel Y

\begin{tabular}{|c|c|c|c|c|c|c|c|}
\hline & & & $\begin{array}{c}\text { Sum of } \\
\text { Squares }\end{array}$ & df & $\begin{array}{c}\text { Mean } \\
\text { Square }\end{array}$ & $\mathbf{F}$ & Sig. \\
\hline \multirow{5}{*}{$\begin{array}{l}\text { Prestasi_Belajar_Aku } \\
\text { ntansi * } \\
\text { Persepsi_Siswa }\end{array}$} & \multirow{3}{*}{$\begin{array}{l}\text { Between } \\
\text { Groups }\end{array}$} & (Combined) & 3649.983 & 36 & 101.388 & 1.775 & .075 \\
\hline & & Linearity & 1910.731 & 1 & 1910.73 & 33.460 & .000 \\
\hline & & $\begin{array}{l}\text { Deviation from } \\
\text { Linearity }\end{array}$ & 1739.253 & 35 & 49.693 & .870 & .652 \\
\hline & \multicolumn{2}{|c|}{ Within Groups } & 1313.417 & 23 & 57.105 & & \\
\hline & \multicolumn{2}{|l|}{ Total } & 4963.400 & 59 & & & \\
\hline
\end{tabular}

Sumber : Penulis 2020

Pada tabel di atas terlihat bahwa nilai pada kolom Sig baris Linierity untuk semua sampel kurang dari 0,05 , sehingga $\mathrm{H}_{0}$ diterima, dengan kata lain bahwa garis regresi hubungan antara varibel $\mathrm{X}_{2}$ dan variabel $\mathrm{Y}$ linier. 
Tabel 6.

Hasil Perhitungan Koefisien Korelasi Pengaruh Variabel $\mathrm{X}_{1}$ dan $\mathrm{X}_{2}$ terhadap Variabel $\mathrm{Y}$

Change Statistics

R Adjusted Std. Error of R Square Sig. F

Model $R$ Square R Square the Estimate Change F Change df1 df2 Change

\begin{tabular}{llllllllll}
\hline 1 & $.680^{\mathrm{a}}$ & .462 & .443 & 5.392 & .462 & 24.453 & 2 & 57 & .000
\end{tabular}

Sumber : Penulis 2020

Hipotesis tersebut pertama diuji melalui analisis korelasi, dari Tabel 6. di atas terlihat bahwa koefisien korelasi ganda pengaruh variabel $\mathrm{X}_{1}$ dan $\mathrm{X}_{2}$ secara bersamasama terhadap variabel $\mathrm{Y}$ adalah sebesar 0,680. Maka berdasarkan nilai $\mathrm{r}$ hitung korelasi tersebut memiliki hubungan keberpengaruhan dalam kategori Kuat. Dimana pengaruh variable $X_{1}$ (Penggunaan Media Komputerisasi) dan Variabel $X_{2}$ (Persepsi Siswa) dalam penelitian ini berpengaruh kuat terhadap variable Y (Prestasi Belajar Akuntansi).

Sedangkan koefisien determinasinya sebesar 46,20\% menunjukkan bahwa besarnya kontribusi Penggunaan Media Komputerisasi dan Persepsi pada mata pelajaran Akuntansi siswa mempengaruhi Prestasi belajar mata pelajaran Akuntansi adalah sebesar $46,20 \%$, sisanya $(53,80 \%)$ karena pengaruh faktor lain yang tidak diteliti.

Tabel 7.

Rekapitulasi Hasil Perhitungan Persamaan Garis Regresi Pengaruh Variabel $\mathrm{X}_{1}$ dan $\mathrm{X}_{2}$ terhadap Variabel Y

\begin{tabular}{|c|c|c|c|c|c|c|}
\hline & \multirow[t]{2}{*}{ Model } & \multicolumn{2}{|c|}{$\begin{array}{c}\text { Unstandardized } \\
\text { Coefficients }\end{array}$} & \multirow{2}{*}{$\begin{array}{c}\text { Standardized } \\
\text { Coefficients }\end{array}$} & \multirow[t]{2}{*}{$\mathbf{T}$} & \multirow[t]{2}{*}{ Sig. } \\
\hline & & B & Std. Error & & & \\
\hline \multirow[t]{3}{*}{1} & (Constant) & 33.149 & 6.231 & & 5.320 & .000 \\
\hline & $\begin{array}{l}\text { Penggunaan Media } \\
\text { Komputerisasi }\end{array}$ & .143 & .047 & .333 & 3.044 & .004 \\
\hline & Persepsi Siswa & .248 & .059 & .458 & 4.184 & .000 \\
\hline
\end{tabular}

Pengujian hipotesis korelasi secara individual yang pertama ini dilakukan dengan Tabel $7 \mathrm{di}$ atas, yaitu dengan memperhatikan kolom Sig untuk baris variavel $\mathrm{X}_{1}$ (Penggunaan Media Komputerisasi). Ketentuan signifikansinya adalah : "jika sig $<\mathbf{0 , 0 5}$ dan $\mathbf{t}_{\text {hitung }}$ maka koefisien regresi tersebut signifikan". Kemudian juga diperoleh bahwa nilai kolom Sig untuk baris variabel $X_{1}$ (Penggunaan Media Komputerisasi) adalah $0,004<$ kurang dari 0,05 berarti koefisien regresi tersebut signifikan, atau dengan kata lain terdapat pengaruh yang signifikan variabel bebas $\mathrm{X}_{1}$ (Penggunaan Media Komputerisasi) terhadap variabel terikat Y (Prestasi Belajar mata pelajaran Akuntansi).

Pengujian hipotesis korelasi secara individual yang kedua untuk variabel $\mathrm{X}_{2}$ (Persepsi Siswa) di atas, yaitu dengan memperhatikan kolom Sig untuk baris variabel $\mathrm{X}_{2}$ (Persepsi Siswa). Ketentuan signifikansinya adalah : “jika sig < 0,05 maka koefisien regresi tersebut signifikan". Dari hasil pengujian tersebut diperoleh bahwa nilai kolom Sig untuk baris variavel $\mathrm{X}_{2}$ (Persepsi Siswa) adalah 0,000< kurang dari 0,05.

Dari Tabel 7. di atas diperoleh persamaan garis regresi yang merepresentasikan pengaruh variabel $\mathrm{X}_{1}$ dan $\mathrm{X}_{2}$ dengan variabel $\mathrm{Y}$ adalah:

Persamaan regresi $\widehat{Y}=33,149+0,143 X_{1}+0,248 X_{2}$ 
Siswa

\section{Persamaan regresi $\widehat{Y}=33,149+0,143$ Media Komputerisasi + 0,248 Persepsi}

Dimana:

$\mathrm{Y}=$ Prestasi Belajar Akuntansi

$\mathrm{X}_{1}=$ Penggunaan Media Komputerisasi

$\mathrm{X}_{2}=$ Persepsi Siswa

Tabel 8.

Rekapitulasi Hasil Perhitungan Pengujian Signifikasi Koefisien Regresi Pengaruh Variabel $\mathrm{X}_{2}$ dengan Variabel Y

\begin{tabular}{llccccc}
\hline & Model & Sum of Squares & Df & Mean Square & F & Sig. \\
\hline 1 & Regression & 1421.645 & 2 & 710.822 & 24.453 & .000 \\
Residual & 1656.955 & 57 & 29.069 & & \\
& Total & 3078.600 & 59 & & & \\
\hline
\end{tabular}

Sumber : Penulis 2020

Untuk pengujian signifikasi garis regresi tersebut bisa dilihat pada Tabel Dari Tabel 8 di atas terlihat bahwa nilai $p$ value $($ sig $)=0.000<0.005$, dan $\mathbf{F}_{\text {hitung }} \mathbf{2 4 , 4 5 3}$. Dengan kata lain bahwa terdapat pengaruh yang signifikan variabel bebas $\mathrm{X}_{1}$ (Penggunaan Media Komputerisasi) dan $\mathrm{X}_{2}$ (Persepsi Siswa) secara bersama-sama terhadap variabel terikat $\mathrm{Y}$ (Prestasi Belajar mata pelajaran Akuntansi).

\section{CONCLUSION}

1. Pengaruh Penggunaan Media Komputerisasi dan Persepsi Siswa secara bersama-sama terhadap Prestasi Belajar Mata Pelajaran Akuntansi

Dari deskripsi data setelah dilakukan analisis korelasi diperoleh koefisien korelasi sebesar 0,680 dan koefisien determinasi sebesaar 46,20\%, setelah dilakukan pengujian dengan program SPSS terbukti bahwa koefisien korelasi tersebut signifikan. Hal ini berarti bahwa terdapat pengaruh variabel bebas $\mathrm{X}_{1}$ (Penggunaan Media Komputerisasi) dan $X_{2}$ (Persepsi Siswa) secara bersama-sama terhadap variabel terikat $\mathrm{Y}$ (Prestasi belajar mata pelajaran Akuntansi). Sedangkan dari analisis regresi diperoleh persamaan garis regresi $\widehat{Y}=\mathbf{3 3 , 1 4 9}+\mathbf{0 , 2 4 8} \mathrm{X}_{\mathbf{1}}+\mathbf{0 , 1 4 3} \mathrm{X}_{\mathbf{2}}$. Nilai konstanta $=\mathbf{3 3 , 1 4 9}$ menunjukkan bahwa siswa dengan persepsi pada mata pelajaran Akuntansi dan Penggunaan Media Komputerisasi paling rendah sulit untuk bisa meraih prestasi belajar yang baik, sedangkan nilai koefisien regresi sebesar 0,248 dan 0,143 menunjukkan bahwa terdapat pengaruh positif variabel bebas $X_{1}$ (Penggunaan Media Komputerisasi) dan $\mathrm{X}_{2}$ (Persepsi Siswa) secara bersama-sama terhadap variabel terikat Y (Prestasi Belajar mata pelajaran Akuntansi), dan setiap ada kenaikan satu nilai $\mathrm{X}_{1}$ (Penggunaan Media Komputerisasi) dan $\mathrm{X}_{2}$ (Persepsi Siswa) maka akan terjadi kenaikan Y (Prestasi Belajar mata pelajaran Akuntansi) sebesar 0,680 .

Persepsi atas mata pelajaran Akuntansi adalah pemahaman siswa tentang mata pelajaran Akuntansi dan mengapa perlu menggunakan media pembelajaran berbasis komputerisasi adalah agar mampu menatap mempersiapkan siswa menghadapi dunia kerja yang menggunakan IPTEK yang sudah maju. Sedangkan prestasi belajar mata pelajaran akuntansi adalah tingkat pencapaian siswa dalam pengetahuan pada mata pelajaran akuntansi, serta pencapaian keterampilan dan sikap yang terkait dengan wawasan tentang ilmu akuntansi. 
Penggunaan media pembelajaran berbasis komputerisasi akan mendorong seseorang untuk mencari ilmu tentang akuntansi sejalan dengan perkembangan IPTEK, baik teoritik maupun praktik. Dengan memiliki persepsi yang positif pada ilmu akuntansi serta kebutuhan akan teori-teori atau ilmu tentang akuntansi yang dilatarbelakangi oleh keinginan, semangat, dan motivasi untuk ahli dibidang akuntansi tersebut maka siswa akan cenderung untuk mengikuti pembelajaran dengan seksama, semangat belajar akan tumbuh dengan baik, serta menekuni ilmu akuntansi tersebut.

2. Pengaruh Penggunaan Media Komputerisasi terhadap Prestasi Belajar Mata Pelajaran Akuntansi

Dari hasil pengujian hipotesis diperoleh bahwa terdapat pengaruh yang signifikan variabel bebas $\mathrm{X}_{1}$ (Penggunaan Media Komputerisasi) terhadap variabel terikat Y (Prestasi Belajar mata pelajaran Akuntansi). Dengan memiliki keahlian yang baik dalam bidang pekerjaan akuntansi, maka siswa akan cenderung untuk mendapatkan teori-teori atau ilmu tentang akuntansi, agar keinginannya untuk menjadi tenaga yang ahli dibidang akuntansi bisa terlaksana dan berhasil. Teori-teori atau ilmu tentang akuntansi tersebut bisa diperoleh dari mata pelajaran Akuntansi, sehingga dengan tekun belajar atau rajin dan tekun mengikuti pelajaran akuntansi, maka disamping ilmu yang mereka butuhkan dan mereka peroleh, nilai atau prestasi belajar yang tinggi pada mata pelajaran akuntansi tersebut niscaya juga akan diperoleh.

3. Pengaruh Persepsi Siswa pada Mata Pelajaran Akuntansi terhadap Prestasi Belajar Mata Pelajaran Akuntansi

Dari hasil pengujian hipotesis diperoleh bahwa terdapat pengaruh yang signifikan variabel bebas $\mathrm{X}_{2}$ (Persepsi Siswa) terhadap variabel terikat Y (Prestasi Belajar mata pelajaran Akuntansi). Sedangkan hasil belajar mata pelajaran akuntansi adalah tingkat pencapaian siswa dalam pengetahuan pada materi pelajaran akuntansi, serta pencapaian ketrampilan dan sikap yang terkait dengan wawasan tentang ilmu akuntansi. Dengan memiliki persepsi yang positif pada ilmu akuntansi maka ada kecenderungan siswa akan tertarik dan termotivasi untuk mengikuti pembelajaran dengan seksama, semangat belajar akan tumbuh dengan baik, serta menekuni ilmu akuntansi tersebut. Jika motivasi dan semangat belajar tinggi maka niscaya prestasi belajar yang tinggi pun bisa diraih.

\section{REFERENCES}

Agung, I Gusti Ngurah. (2004). Statistika Penerapan Model Analisis untuk Tabulasi Sempurna dan Tidak Sempurna dengan SPSS. Jakarta: Raja Grafindo Persada

Agung, I Gusti Ngurah. (2004). Statistika Penerapan Model Analisis untuk Tabulasi Sempurna dan Tidak Sempurna dengan SPSS). Jakarta : Raja Grafindo Persada.

BSNP Departemen Pendidikan Nasional. (2006). Petunjuk Teknis Pengembangan Silabus dan Contoh/Model Silabus. Jakarta.

Damayanti, M. Ria, A. \& Zainuddin, D. (2018). Pengaruh Pelatihan Sertifikasi Zahir Accounting terhadap Kesiapan Kerja Mahasiswa Program Studi Pendidikan Ekonomi. Jurnal Prosiding LPPM Unindra 2018

Dendy, Sugono, (2008). Kamus Besar Bahasa Indonesia Edisi Keempat. Jakarta: Gramedia

Djali dan Pudji Mujiono. (2008). Pengukuran dalam Bidang Pendidikan, Jakarta: Grasindo. 
Djamarah, Syaiful Bahri dan Aswan Zain. (2006). Strategi Belajar Mengajar (Edisi Revisi). Jakarta: Rineka Cipta.

Ibrahim, A. Suparman. (2014). Aplikasi Komputer Dalam Menyusun Karya Ilmiah. Tangerang: Pustaka Mandiri

Irwanto. (1994). Psikologi Umum. Jakarta: Gramedia Pustaka Utama.

Jalaluddin, Rakhmat. (2011). Psikologi Komunikasi. Bandung: Remaja Rosdakarya.

Jihad, Asep dan Abdul Haris. (2008). Evalusasi Pembelajaran. Yogyakarta : Multi Presindo.

Muslich, Masnur. (2007). KTSP Pembelajaran Berbasis Kompetensi dan Kontekstual. Jakarta : Bumi Aksara.

Muchith, Saekhan. (2008). Pembelajaran Kontekstual. Semarang:RASAIL Media Group.

Robbins, Stephen P. Terj. Yusuf Udaya. (2004). Teori Organisasi, Struktur, Desain dan Aplikasi. Jakarta : Arcan.

Slameto. (2002). Belajar dan Faktor-Faktor yang Mempengaruhinya. Jakarta: PT. Raneka Cipta.

Sudijono, Anas. (2008). Pengantar Evaluasi Pendidikan. Jakarta : PT Raja Grafindo Persada.

Sudjana, Nana. (2004). Penelitian Hasil Belajar Mengajar. Bandung : Remaja Rosda Karya.

Sudjana, Nana dan Ibrahim. (2004). Penelitian Dan Penilaian Pendidikan. Bandung: Sinar Baru Algesindo.

Sugiyono. (2007). Metode Penelitian Pendidikan Pendekatan Kualitatif, Kuantitatif dan $R \& D$. Bandung: Alfabetha. . (2018). Metode Penelitian Kombinasi (Mix Methods). Bandung: Alfabeta.

Tirtaraharja, Umar dan S. L. La Sulo. (2008). Pengantar Pendidikan. Jakarta: PT. Rineka Cipta.

Undang-Undang Republik Indonesia Nomor 20 Tahun 2003 Tentang Sistem Pendidikan Nasional.

Wahana Komputer. (2010). Mengolah Data Hasil Penelitian dengan SPSS 17. Semarang: Penerbit Andi. 